\title{
Ivan Merz, student na Vojnoj akademiji u Bečkom Novom Mjestu 1914. godine
}

\author{
Zdravko Matic**, Krešimir Lagetar**
}

\begin{abstract}
Sažetak
Autori na temelju arhivske građe, novinskih članaka i recentne literature istražuju boravak Ivana Merza na Vojnoj akademiji u Bečkom Novom Mjestu. Iako akademija nije bio njegov izbor, nakon mature po želji roditelja mladi Merz se upisao na Vojnu akademiju u Bečkom Novom Mjestu. Bilo je to teško razdoblje u njegovu životu, kako i sam priznaje najprije u svojem Dnevniku a kasnije se povjerio i svojemu gimnazijskomu profesoru Ljubomiru Marakoviću. Grubost i nemoral na Vojnoj akademiji bili su svakodnevica, a uz činjenicu da će čitav život morati raditi posao koji nije želio bili su mu posve oprečni. Njegova želja i afinitet bili su da studira književnost i postane profesor, te je nakon tri mjeseca, uz suglasnost roditelja, napustio Vojnu akademiju, na kojoj je boravio od 12. rujna do 22. prosinca 1914. godine.

Ivan Merz je odlukom Pape Ivana Pavla II. 22. lipnja 2003. u Banjoj Luci proglašen blaženikom Katoličke Crkve.

Ključne riječi: Ivan Merz, akademac, Terezijanska vojna akademija, Bečko Novo Mjesto, Ljubomir Maraković, studij
\end{abstract}

\section{Odabir i odlazak na Vojnu akademiju u Bečko Novo Mjesto}

Po završetku realne gimnazije u ljetu 1914., Ivan Merz 1 želio je poći na studij filozofije i književnosti, koji ga je oduševljavao i za što je imao istančan smisao.

* Izv. prof. dr. sc. Zdravko Matić, Hrvatsko vojno učilište »Petar Zrinski«, Zagreb. Adresa: Ilica 256b, 10000 Zagreb, Hrvatska. E-pošta: zdmatic@gmail.com

** Krešimir Lagetar, prof., Osnovna škola Laslovo. Adresa: Školska 1, 31214 Laslovo, Hrvatska. E-pošta: klagetar@gmail.com

1 Ivan Merz (Banja Luka, 16. prosinca 1896. - Zagreb, 10. svibnja 1928.) osnovnu školu i realnu gimnaziju pohađao je u Banjoj Luci. Provevši kraće vrijeme u Vojnoj akademiji u Bečkom Novom Mjestu, upisao se 1915. na Bečko sveučilište, želeći se — kao profesor — posvetiti podučavanju i odgoju mladeži u Bosni, po primjeru svojeg profesora Ljubomira Marakovića. U ožujku 1916. pozvan je u vojsku te je krajem iste godine poslan na talijansko bojište, gdje je proveo cijelu 1917. i 1918. godinu. Ratna su iskustva pridonijela duhovnomu sazrijevanju mladog Ivana Merza. Nakon rata vratio se u Beč i nastavio studij (1919. — 1920.), a potom je u Parizu (1920. — 1922.) nastavio studij književnosti i usput je pripremao svoju doktorsku disertaciju naslovljenu Utjecaj 
Međutim, njegovi roditelji favorizirali su vojno zanimanje. Izbor je pao na Terezijansku vojnu akademiju u Bečkom Novom Mjestu, koja je imala velik ugled u Austro-Ugarskoj i koja je pripadala među vojno-odgojne i obrazovne zavode. ${ }^{2}$ Terezijanska vojna akademija u Bečkom Novom Mjestu bila je dobro rješenje, smatrao je njegov otac Moritz, s obzirom na to da je ona upisivala kandidate koji su upravo završili nižu i višu vojnu ili civilnu realku, a te su realke trebale služiti kao pripravnički zavodi za stupanje u vojnu akademiju i kadetsku školu. Odgovor na pitanje zbog čega je Moritz odabrao upravo Terezijansku vojnu akademiju treba vjerojatno tražiti u tome što je on završio četverogodišnju Pješačku kadetsku školu koju je pohađao u Pragu i završnu godinu u Temišvaru. ${ }^{3} \mathrm{~S}$ druge strane, znao je da je Terezijanska vojna akademija u Bečkom Novom Mjestu akademija s dugom tradicijom i ugledom te relativno blizu Banje Luke te da može pružiti njegovu sinu izvrsno obrazovanje koje će mu omogućiti siguran posao u Monarhiji.

Tako je razmišljao stari i iskusni austrougarski časnik Moritz Merz, koji je napose zbog toga inzistirao na Vojnoj akademiji, a majka Terezija favorizirala je časnički poziv radi egzistencijalne sigurnosti (siguran posao, državna plaća, čast i ugled u društvu). Osim toga, bili su odlučni da pođe u Bečko Novo Mjesto jer su u Austriji imali dosta prijatelja, napose otac Moritz među austrijskim časnicima koji su bili voljni pomoći njihovu sinu. K tomu, prednost pri prijamu u Vojnu akademiju imala su djeca austrougarskih časnika, a uvjet su bili i nacionalna pripadnost kandidata, tjelesna sposobnost i znanje njemačkog jezika, te da kandidat nije bio stariji od dvadeset godina. Da bi se uopće mogao natjecati, svaki je budući pitomac morao ispunjavati sljedeće formalne uvjete: da ima austrougarsko državljanstvo, tjelesnu sposobnost i da nije stariji od dvadeset godina. Sve te formalne uvjete Ivan Merz je ispunjavao. Osim toga, prilikom primanja u vojne škole zakonom je bilo određeno da na »platežna mjesta imadu tražbeno pravo sinovi svih austrijsko-ugarskih državljana nu prednost imadu sinovi častnika, vojnih, dvorskih i civilnih državnih činovnika «. ${ }^{4}$ Upravo to je išlo u prilog mladomu Merzu jer je imao osiguranu državnu stipendiju. Moritz Merz

litrugije na francuske književnike od Chateaubrianda do danas, kojom je na Sveučilištu u Zagrebu stekao naslov doktora filozofije. Po povratku iz Pariza 1922. godine odmah se uključio u Hrvatski katolički pokret, te je iste godine postao predsjednikom Hrvatskog katoličkog omladinskog saveza.

Zajedno s Ivanom Protulipcem i ostalim katoličkim djelatnicima zaslužan je za osnivanje Hrvatskog orlovskog saveza, a na Merzovo zauzimanje uvedena je Katolička Akcija u Hrvatskoj. Intenzivno se zauzimao za izvanstranačku Katoličku Akciju i depolitizaciju Hrvatskog katoličkog pokreta. Umro je na glasu svetosti. Papa Ivan Pavao II. proglasio je Ivana Merza katoličkim blaženikom 22. lipnja 2003. godine u njegovu rodnom mjestu Banjoj Luci.

2 Osim nje u tu skupinu su ubrajani: Vojni kolegij (Militarkollegium) u St. Poltenu (Sv. Hipolitu), Vojna tehnička škola u Hranicu (Mahrisch - Weibkirchen), Tehnička akademija u Beču i još tri niže vojne realke u Kisegu, Kismartonu (Eisenstadt) i Košicama. Prvomil Krbek, C. kr. Austrougarske realke sa stanovišta pedagogijskoga, Zagreb, 1889, 10-11.

3 Österreichisches Staatsarchiv (ÖSK), Kriegsarchiv, K. u. K. Kriegministerium (ÖSK), Qualifikationsliste Moritz/Moriz Merz, s.1.

4 Obrambeni zakon i Provedbeni naputak, Budimpešta, 1908, 42. 
potajno se nadao da će njegovu sinu biti i zbog toga znatno lakše boraviti u akademiji, nego njegovim kolegama. Merz je završio realku u Banjoj Luci. Za prijam u neku od vojnih škola kandidat je morao (ali ne nužno) završiti nižu ili višu realku. Te su škole trebale služiti kao pripravnički zavodi za upis u vojnu akademiju i kadetsku školu. ${ }^{5}$

\section{Liječnički pregled u Banjoj Luci}

Natječaj za prijam u Vojnu akademiju u Bečkom Novom Mjestu bio je objavljen u veljači 1914. godine, na Vojnoj akademiji i u službenim glasilima Austro-Ugarske Monarhije. Zamolbu za prijam u Vojnu akademiju osobno je poslao njegov otac Moritz u ožujku 1914., iako je mladi Merz službeno doznao da ide u Wiener Neustadt tek u travnju 1914., uoči liječničkog pregleda koji je trebao obaviti svaki kandidat. U dopisu što ga je Okružno vojno zapovjedništvo poslalo u travnju na kućnu adresu pisalo je da pripravnik Hans Merz ima obaviti liječnički pregled 8. travnja 1914. u Banjoj Luci. ${ }^{6}$ Domovnicu mu je već prethodno izvadio ujak u Michelsbergu 5. veljače 1914. i poštom dostavio na kućnu adresu. ${ }^{7}$ Iako nije bio oduševljen svojim budućim pozivom, iz poslušnosti prema roditeljima podvrgnuo se detaljnomu liječničkomu pregledu 8. travnja u Vojnoj ambulanti pri Zapovjedništvu u Banjoj Luci. Predsjednik liječničkog povjerenstva dr. Jaroslav Hajnovsky, stožerni liječnik, ocijenio je da je Hans Merz sposoban za prijam u Carsku kraljevsku terezijansku vojnu akademiju u Wiener Neustadtu, uz napomenu tjelesnog nedostatka pod točkom 11. Iz liječničkog uvjerenja razvidno je da je po svim medicinskim parametrima bio dobrog zdravlja. ${ }^{8} \mathrm{Na}$ dan pregleda bio je star 17 godina i 4 mjeseca. Bio je visok $173 \mathrm{~cm}$, srednje jačine. U nekoj dobi, kao dječak, prebolio je šarlah, ali bez posljedica. Oštrina vida mu je bila nešto smanjena (lijevo oko - 1,5 uz mogućnost korekcije zbog astigmatizma). ${ }^{9}$ S obzirom na stanje vida Ivan Merz je na temelju uputnice Zapovjedništva popunidbenog okruga Banja Luka (Erganzungsbezirk-Kommando) 19. svibnja 1914. upućen u Carsku i kraljevsku posadnu bolnicu broj 23, u Zagreb, na kontrolni pregled očiju. Funkcionalni pregled očiju pokazao je da je desno oko $\mathrm{V}=$ 6/12 ( $\mathrm{s}+1,5$ diop-trijom), skoro 6/8; lijevo $\mathrm{V}=6 / 12$ ( $\mathrm{s}+1,5$ dioptrijom), skoro 6/8. Objektivni pregled je ukazivao desno - vodoravni meridijan: dalekovidnost dioptrija 7; lijevo - dalekovidnost dioptrija 6,5; desno - okomiti meridijan:

5 Ferdinand Schmid, Das Heeresrecht der osterreichisch-ungarischen Monarchie, Beč — Leipzig, 1903, 388.

6 Arhiv Ivana Merza (dalje: AIM), Poziv za liječnički pregled.

7 AIM, Land Bohmen, Polit. Bezirk: Plan, Register: 167, Beimat — Schein, Name: Hans Merz, Michelsberg, 5. febr 1914, Hofner.

8 AIM, Aerztliches Gutachten, Banja Luka, 8. travnja 1914.

9 AIM, fond: Osobni dokumenti bl. Ivana Merza (od rođenja do smrti), Aerztliches Gutachten, über nachbenannten Aspiranten behufs dessen Aufnahme in die k.u.k. Theresianische Militärakademie in Wr. Neustadt, K.u.K. Ergnzungsbezirkskommando in Banja Luka, Z.P. Nr. 79, Banja Luka, 8. travnja 1914. 
dalekovidnost dioptrija 6; lijevo - dalekovidnost dioptrija 4,5; stanje odgovara astigmatizmu. U zaključku liječničkog nalaza navedeno je: oštrina vida oba oka nakon korekture konveksnim lećama iznosi skoro 6/8, a bila je uvjetovana hipermetropskim astigmatizmom. U potpisu, pukovnik, dr. Fischer, pukovnijski liječnik. ${ }^{10}$

Iako liječnička svjedodžba svjedoči da je Ivan Merz prošao liječnički pregled, pismo upućeno majci Tereziji od 1. veljače 1915. baca novo svjetlo na taj događaj. U pismu, između ostalog, on piše majci kako se treba krajem veljače 1915. pojaviti na pregledu u vojsci, ali je uvjeren da neće biti primljen, te podsjeća majku na koji je način bio primljen na Vojnu akademiju u Wiener Neustadtu. ${ }^{11}$

Upravo zbog zdravstvenih razloga roditelji su ga poslali u Opatiju na odmor, gdje je proveo od 19. do 27. srpnja 1914. godine Željeli su da se odmori i oporavi od naporna rada u realki, prije odlaska u Wiener Neustadt. U Opatiji je Merz pronašao mir i mogao se opustiti u raznim sadržajima. ${ }^{12}$ Kniewald navodi da se mladi Merz, za volju svojih roditelja, pokušao odreći i svojih literarnih sklonosti i postati časnik. ${ }^{13}$ Kod svojih kolega iz realke nailazio je na čuđenje i laganu nevjericu kada su doznali da odlazi u Vojnu akademiju, koja je bila poznata po vojnom »drilu « i konvencionalnosti. Na njihov eksplicitan upit da im odgovori na pitanje iz kojih razloga odlazi na Vojnu akademiju kada je protiv rata, on je mirno i staloženo govorio: »Ideal mi je pravednost i možda ću pasti kao žrtva ovome. «14 Roditelji su bili neumoljivi, vjerujući da čine ono najbolje za svojeg sina. Iako je načelno prihvaćao ideju, vrlo teško mu je pala takva inicijativa, makar je potekla i od roditelja, jer se to kosilo s njegovim načelima, o čemu piše u svojem dnevniku: »S mamom je bilo malo prepirka: ona sanja da ću ja u generalni stožer, što se ne slaže s mojim principima. Užasno je kad se tjera da se bira po njihovoj volji.«15 Ipak, nakon dugotrajnih razgovora, više iz ljubavi prema roditeljima, popušta pod pritiskom te je 12. rujna 1914. zajedno s ocem otputovao na Terezijansku vojnu akademiju u Bečkom Novom Mjestu na klasifikacijski ispit. Ispit je bio na njemačkom jeziku i polagao se u prostorijama Terezijanske vojne akademije. ${ }^{16}$ Iako je ispunio sve formalno-pravne uvjete za upis, bio je to, po svemu sudeći, najtužniji dan u Merzovu životu — dan kada je formalno započeo vojnički život, protivno njegovim osjećajima i dobroj nakani.

10 AIM, Konstatierungsbefund, K.P.N: 277; E.N: 336, Zagreb, 19. svibnja 1914.

11 AIM, Pismo Ivana Merza Tereziji Merz od 1. veljače 1915.

12 Dnevnik Ivana Merza (dalje: DIM), 19. VII. 1914., Sabrana djela, sv. 4., Postulatura za kanonizaciju bl. Ivana Merza - Zagreb, 2014, 73-74.

13 AIM, Dragutin KNIEWALD, Ivan Merz /1896 - 1928/, Zagreb, 1964, 98. [Rukopis.]

14 DIM, 27. III. 1914., 39.

15 DIM, 21. VI. 1914., 64-65.

16 AIM, K.u.K. Theresianische Militärakademie, Wr. Neustadt, am November 1914. 


\section{3. Život u Vojnoj akademiji i potpora Ljube Marakovića}

Njegov otac Moritz, koji ga je dopratio do ulaza u Vojnu akademiju, napuštajući sina ipak nazire da on nije za časnika. Mnogo godina poslije on je kazao:

Još jedan zagrljaj i poljubac i Ivan je ostao u životu prvi put u tuđini predan sam sebi. Iza 5 do 6 koraka okrenuo sam se još jednom, da mu rukom zadnji zbogom domahnem [...] u taj čas vidio sam ga još na istom mjestu [...] njegove su oči bile širom otvorene, zagledane u daljinu, i opažale su se suze u njima. Tada sam prvi put otkrio njegovu dušu [...] znao sam: moje dijete nije za oficirsko zvanje. ${ }^{17}$

Merz se na Akademiji brzo uklopio u vojnički život. Školovanje u Akademiji trajalo je dvije godine. Po ustroju, Akademija je školovala časnike rodova pješaštva, strijelaca i konjaništva. ${ }^{18}$

Merz u svojem dnevniku navodi da se nastava održavala prijepodne, a praktične vojne vježbe imali su poslijepodne. Međutim, nećudorednost i permanentna verbalna i fizička grubost s kojima se svakodnevno susretao bile su posve oprečne njegovoj koncepciji shvaćanja čovjeka i svijeta i ostavljale su ga uvijek začuđenog, zbog čega nije mogao prihvatiti da će čitav život raditi posao koji ne voli, i to još u takvom okruženju. Svoje boli i sumnje bilježio je najprije u dnevniku, a kasnije ih je priopćavao svojemu gimnazijskomu profesoru Ljubi Marakoviću i roditeljima. Tako u svojem prvom dnevničkom zapisu na akademiji 21. rujna 1914. zapisao je:

Pošto sam stupio u Vojnu akademiju, znači da moram postati dobar vojnik. No sa mnom je to sasvim drukčije. Volju za vojništvom nisam nikad imao, ali da olakšam život roditeljima, stupio sam ovamo. S ovim postupkom sam si izabrao dvije dužnosti koje ću bezuvjetno činiti: moje daljnje literarno i umjetničko izobražavanje, te vršenje vojne dužnosti. Vojnik sam rado, ali ovdje nisu pravi vojnici. Ideal njima nije nikakva nedostižna stvar, nego život za cara. Ispovijed koju bih toliko želio, kao ni pričest, ne mogu primiti. Sam ovdašnji svećenik je nedubok. U crkvi kaže, da su za vojnika ove tri stvari: krepost, marljivost i religija. Kao da je vojnik drugi čovjek. Krepost, marljivost, religija, to je nelogično. Religija sve kreposti sadržava. Jedan se je akademičar ubio. Nije čudo da se je samo jedan ubio. Njima je ideal biti vojnik, zašto, kako o tome se ne misli. Kad taj ideal iščezne, ne znajući što je svrha života, neće više da živi. Život nije uživanje, nego žrtva. ${ }^{19}$

Osobno je bio razočaran i potresen uvjetima na Vojnoj akademiji, ali još više ambijentom i odnosom kadeta i nadređenih, o čemu je pisao i svojemu profesoru iz gimnazije Ljubi Marakoviću i konačno roditeljima. ${ }^{20} \mathrm{U}$ razglednici kojom se javio Marakoviću napisao mu je da je uspješno položio klasifikacijski ispit na Vojnoj akademiji, ali da je »sve pusto i nepoznato« i da je sve posve jednolično i uniformno. Merz ga moli da mu pošalje popis knjiga kako bi nastavio započeti

17 Mavro MERZ, Iz očevih uspomena, Život, 5. V. 1928, 274.

18 Schematismus für das K. u. K. Heer und für die K. u. K. Kriegsmarine für 1914, Wien, 1914, 116.

19 DIM, 21. IX. 1914., 88.

20 DIM, 15. X. 1914., 89-90; 24. X. 1914., 91-92. 
posao iz gimnazije. Potajno se uvijek nadao i želio biti poput svojeg gimnazijskog profesora Ljube Marakovića, ${ }^{21}$ o kojem je uvijek imao riječi hvale.

U pismu od 28. rujna 1914. Maraković piše Merzu:

Lijepa Vam hvala na karti i na sjećanju. Čestitam na uspjehu i znam, da ste sigurno više znali, nego kako pišete. Dakako, da Vam je za sad tamo sve pusto i nepoznato, ali mislim, da ćete se i bez mene već snaći. Knjige kojih ste adresu željeli ove su: Geisteshelden, Biographien Bd 43: Turgenjev, v. E. Borkowsky, Berlin Ernest Hofmann Co. Svakom je svesku priklopljen popis ostalih brojeva 'Geisteshelden', te možete još koji naručiti. Ja sam čitao Schiller od Harnaca i Goethe od R.M. Meyerov (Preisegekront), te su uglavnom dobra djela, osobito posljednje spada među najbolja, onda: Die Kunst zu beten, Ars orandi — von Msgr. Baron de Mathies, Petrus, Verlag Trier (moje izdanje je u Pergamnbandu, možete dobiti, i u platnu, jeftinije, i u koži, skuplje). Kad pročitate Ars oranti uvjeren sam, da ćete željeti još štogod pročitati od istog pisca, osobito od djela, u kojima zasjeca u praktičnu stranu socijalnih, kulturnih i religioznih problema naših dana. Ako još šta trebate, drage ću Vam volje priopćiti ili razjasniti. To u ostalom i tako već znate. ${ }^{22}$

I na kraju pisma Maraković ga izvješćuje o aktualnostima kod kuće i o poznatim osobama iz Banje Luke koje su otišle u rat. »[...] prekjučer je otišlo odavde 120 ljudi Schutzkova, koji su se svojevoljno javili, u Olovo - Vareš, da tamo čuvaju željeznicu i tvornice. Od naših đaka su otišli, kako sam u vrevi mogao razabrati, Beck, Betunac, Köhler, Kučinić i Plach a bit će još koji. Rastanak je bio vrlo lijep, ljepši nego ijedan, što sam ovdje vidio [...]. ${ }^{23}$

\section{Surovi život u Vojnoj akademiji}

Već nakon kratkog boravka u Vojnoj akademiji, Merz je imao svoje viđenje o okružju u kojem je živio i djelovao. Kao čovjek bio je razočaran moralnom pokvarenošću ljudi s kojima je živio na akademiji. »Nikako se nisam nadao da može biti ovakvih ljudi. U prvi mah sam se zgrozio svemu, dapače sam i plakao « ${ }^{24}$ Bio je konsterniran postupcima pojedinih kolega koji su stalno izmišljali, konstruirali lažne priče, i dovodili ili stavljali u kontekst mirnog i povučenog kadeta Merza, od kojih se stalno trebao braniti. Bio je zatečen pokvarenošću akademičara iz kojih je svakodnevno izbijala podlost. Bilo mu je neshvatljivo takvo površno

21 Ljubomir Maraković rođen je u Topuskom na Banovini, 17. lipnja 1887, a umro je u Zagrebu 22. veljače 1959. godine, U Travniku je završio isusovačku Klasičnu gimnaziju, a slavistiku i germanistiku je doktorirao u Beču. Službovao je u Banjoj Luci, Sarajevu i Zagrebu. Njegova djela su: Nov život (1910.), Novi pripovjedači (1929.), Nauka o književnosti (1943.) i dr. Svojim humanističkim pristupom snažno je utjecao na mladog Ivana Merza, koji je kasnije krenuo njegovim stopama. Petar Grgec, Životopis dr. Ljubomira Marakovića, Arhiv Franjevačkog samostana na Kaptolu, Hrvatska franjevačka provincija Sv. Ćirila i Metoda, Kaptol 9, Zagreb. Kutija A - 24: Svjetovnjaci u hrvatskom katoličkom pokretu, III, Ljubomir Maraković, obiteljski životopis do 1892. (rukopis).

22 AIM, pismo dr. Ljubomira Marakovića, Ivanu Merzu s nadnevkom 28. IX. 1914.

23 Isto.

24 DIM, 14. X. 1914., 89. 
i infantilno ponašanje kolega, budućih časnika koji su trebali biti moralni stup države. O tome Merz piše bez uvijanja:

Upravo, kad sam jučer pisao, prekinuli su me užasnom ironijom i napadajima dosta vješto izmišljenim, da se sam kadkad nisam mogao izvući. Danas se sam tome čudim jer su napadaji bili užasno plitki. Dapače, kad sam govorio, pretpostavljajući da znaju fundamente kulturne historije, da nam ideali moraju biti jednakost, bratstvo i sloboda (u kršćanskom smislu), skočiše na me i kažu, da su plodovi ovog revolucija. Ne priznaju ni jednu stranu revolucije. Dapače, ništa im nisam mogao dokazati. Sa sažalnim me pogledom i najgluplji gledaju, što sam rekao, da je rat bestijalizam i da sam protiv rata. Kad sam im napomenuo Bertu Suttnerovu, ${ }^{25}$ nijedan za nju nije ni čuo: »vojna visoka škola«, a kako malo znaju! No sve da su oni za rat i proti Vjere, opet bi čovjek rekao, da je to disputa oko kulturnog pitanja i oni, pa i ja, težimo za dobrim. No 'drvo će se poznati po plodovima'. U najuzvišenijim časovima najbolje izbija niskost ljudi. Bio je Ausmusterung. ${ }^{26}$

Iako je bio svakodnevno izložen raznim napadajima i podmetanju, u njemu se opet pobudio osjećaj za književnost i filozofiju. Uspijeva ponešto i pročitati:

[...] svršio sam dio analize Dima, pročitao Turgenjevljeva König Lear der Steppe, nešto iz Brunetijerova Balsaca i jedan iz Langescheidta. Ljubi sam pisao i on mi je poslao adrese Turgenjeva iz kojega se na maturi prevađalo te Die Kunst zu beten. ${ }^{27}$ S ostalim kolegama se marljivo dopisujem. Moj Ante primljen je u vojnike. Kad pomislim kako je on dobar i plemenit, a kakvi su ovdašnji moji kolege. Plach, Köhler i Kratena bili su na granici u Schulzenpanu. König u nedjelju dolazi ovamo [...]. ${ }^{28}$

Makar je imao mnogo svakodnevnih obveza na Vojnoj akademiji, nedostajali su mu razgovori s dragim Ljubom, Lubanom kako ga je od milja nazivao, druženje s ljudima koji su slično razmišljali i promišljali o stvarnosti, ljudskom bitku, istini, pravdi i pravednosti. Nedostajala mu je živa riječ, potreba za komunikacijom na istoj razini i želja da napreduje, da se razvija intelektualno i duhovno. Upravo sve to nije imao na klasičnoj Vojnoj akademiji u Bečkom Novom Mjestu, gdje je trpio najviše psihički.

Svaki izlazak iskoristio je za razgledavanje kulturno-povijesnih znamenitosti i ostalih sadržaja koje je nudio Beč i njegova okolica. Prema Statutu Vojne akademije, akademci su imali svakog četvrtka »izlazak« do 21 sat, što su gotovo svi revno koristili. Tako je za jednog izlaska Merz bio u Beču, gdje je slušao jednu Wagnerovu operu. Zakasnio je na vlak kojim se trebao vratiti u Bečko Novo Mjesto. Zbog tog formalnog prekršaja kažnjen je s dva dana zatvora. ${ }^{29}$

25 Bertha von Suttner (1843. - 1914.), austrijska književnica. Zalagala se za mir u svijetu i dobila Nobelovu nagradu za mir 1905. godine. Godine 1913. Naklada Luč u Zagrebu, objavila je na hrvatskom jeziku njezinu knjigu Dolje s oružjem!

26 Ausmusterung (njem.) — stavnja, vizita (vojno-medicinski izraz za pregled mladića za prijem u vojsku)

27 M. J. Scheeben, Die Kunst zu beten - Umjetnost moljenja. Tu mu je knjigu preporučio njegov bivši profesor Lj. Maraković. Merz si ju je nabavio is velikom duhovnom korišću čitao za vrijeme boravka u Vojnoj akademiji.

28 DIM, 15. X. 1914., 89-90.

29 Dragutin Kniewald, Dr. Ivan Merz — život i djelovanje. Zagreb, 1932, str. 32. 
»Jedino se rastužim i teško mi bude kada vidim da učinim nešto zlo. Netko me ljuti i ljuti, a ja u ljutnji za njim bacim stolicu i sam ne znam kako to, nazovem ga svinja. Bože, daj da se tako što više ne dogodi! Onda sam jednom slagao govoreći g. kapetanu Slusarezu da nisam znao da se ide na bataillon-inspekciju, a u istinu bilo mi je dosadno ići na nju; i to se neće, ne, ne smije nikada dogoditi! [...].«30 O razlozima zašto je dospio u zatvor pisao je i svojemu ocu Morizu, kojega iskreno izvješćuje o stanju na akademiji i pita što mu je činiti. ${ }^{31}$ Dok je boravio u zatvoru razmišljao je o temeljnim egzistencijalnim pitanjima: prolaznosti života, njegovu odnosu prema Bogu, putu prema savršenosti i kako uspostaviti odnos sa živim Bogom. Stoički je podnosio sve neugodnosti koje je doživljavao, ali je istovremeno u njemu sve više sazrijevala odluka da zauvijek napusti Vojnu akademiju u Wiener Neustadtu i posveti se studiju filozofije i književnosti.

Dok je boravio u zatvoru pročitao je knjigu Die Kunst zu beten (Umjetnost molenja). On je otvoreno priznao da vjeruje u Boga, i da vjeruje Bogu. Vrlo slikovito dočarava svoj položaj krhkog slabog ograničenog čovjeka naspram Bogu i želju da bude otvoren konstantno prema njemu. Merz je uvjeren da čovjek participira na Božjem Bitku. On kaže: »Ali ono malo Prometejeve iskre, djeličak od djelca Svevišnjega, vuče me Ovome i dokumentira njegov opstanak. Kano što čovjek koji još nije sasvim zagazio u blatu želi da se razgovara s pametnijim od sebe, tako isto duh svom žestinom teži za savršenim, za velikim Duhom «. ${ }^{32}$ Molitva je razgovor s Bogom prema njemu, dijalog, obostrana komunikacija. Upravo to priznavanje Svevišnjega je religija: »[...] kao što Baron kaže. Taj razgovor sa Svevišnjim, ta veza, priznavanje Svevišnjega je religija. Religija je bez molitve mrtva ${ }^{33}$

S obzirom na svoj nezavidan položaj Merz se ponovno obratio Marakoviću pismom u kojem ga izvještava o stanju na Vojnoj akademiji i okružju u kojem živi i djeluje. Bila je to pomalo iracionalna situacija iz koje je tražio intenzivno i iskreno izlaz. U pismu kojim se javlja Marakoviću moli ga za konkretan savjet kako se osloboditi objektivnih teškoća koje ga muče. Tu su i sumnje koje ga drže podvojenim i niz egzistencijalnih pitanja koja se odnose na vjeru. ${ }^{34}$

Maraković mu je odmah odgovorio biranim riječima, ali neizravno mu je dao do znanja da je na njegovoj strani i da odobrava njegov stav te ga podržava koliko je to do njega. ${ }^{35} \mathrm{U}$ pismu od 24. studenog 1914. Maraković mu, između ostalog, piše:

Hvala na iskrenosti, kojom ste mi povjerili svoje nazore u listu, ma da će biti teških žrtava i prijegora, ta škola života samo će Vam koristiti, jer ćete tim jasnije i sigurnije naći svoj cilj. Sad istom možete vidjeti, da vjersko uvjerenje nije fraza ni hipokrizija, nego prijeka i krvava potreba čovjeka, koji u današnje rastrovano i rasklimano vrije- 
me hoće da živi svojim životom, da teži za svojim ciljem i da postavlja svoje vrednote u životu. Uostalom ne treba da Vam mnogo govorim: vidim, da život ozbiljno shvaćate, a to sam i otprije znao i veselio se Vašoj evoluciji. Znam, da se ne ću prevariti [...]. ${ }^{36}$ čita.

U drugom dijelu pisma Maraković kao da ga želi još snažnije potaknuti da

Znate, da i ja najviše u knjigama živim. I u muzici. Ne propustite slušati Wagnera, kad god možete, ali se uvijek dobro pripravite [...]. Ne zaboravite ni na ljude, promatrajte, proučavajte: danas doživljujemo mnogo, i ako svašta. I ako ovo vrijeme nije uvijek 'veliko', događaji su svakako veliki. A nadam se da ste u 'Hrvatskoj' našli i dobrih drugova. ${ }^{37}$

Iz Marakovićeva pisma je razvidno da je potpuno shvaćao situaciju u kojoj se njegov bivši učenik nalazio. Zato je bio obazriv prema njemu u želji da svlada krizu u kojoj se nalazi i dođe do svojeg cilja. Marakoviću je bilo jasno da su Merzovi roditelji namijenili sinu vojničku karijeru za koju on nema nikakva afiniteta, nego je to činio iz dubokog poštovanja prema njima. Zato je nastojao amortizirati njegove navrle frustracije i nezadovoljstvo ne želeći se ni u jednom trenutku miješati u njihov odnos i tako sve još više zakomplicirati.

Merz je želio postati književnik i profesor poput Marakovića, zato je njegova odluka da napusti Vojnu akademiju bila još snažnija. Iz njegova dnevnika doznajemo da je na Akademiji uistinu bio nesretan, čak je bio odlučio pobjeći. »Dugo nisam pisao. Prošlo je već 14 dana, a ja sam dobio pojam o životu. Nikako se nisam nadao, da može biti ovakvih ljudi. U prvi mah sam se zgrozio svemu, dapače sam i plakao. «8 Dugo je planirao otići u Beč i poslušati Wagnera o čemu mu je i Maraković pisao i sugerirao u pismu od 24. studenog 1914. godine. Tako, između ostalog, piše: »Ne propustite slušati Wagnera kadgod možete, ali se uvijek dobro pripravite. K tome komorne koncerte u velikim glazbenim dvoranama. Znam, da Vi to sve znate, ali Vam napominjem, da ne propustite koješta kao ja, pa da Vam poslije bude žao «. ${ }^{39}$

Iako je nailazio na različite neprilike i podmetanja od samog dolaska u Vojnu akademiju, tek 14. listopada 1914. odvažio se ocu napisati otvoreno pismo u kojem ističe da je postalo neizdrživo živjeti s ljudima »koji tako nisko misle, govore i čine, da ne znam što da činim. Svaka je njihova riječ nova uvreda. Nisam slutio, da ću doći u ovakvu okolinu. Ti vidiš, da sam ti iskren i usrdno te molim da me savjetuješ što da činim «. ${ }^{40}$ Starog Moritza je pismo zaprepastilo jer je znao, kao iskusan časnik, da mu sin piše samo istinu, ali je ipak nastojao sina umiriti riječima da se nastoji priključiti onim pitomcima koji su bili korektni i s kojima nije dolazio u sukob. Međutim, mladi Merz nije vidio smisla svojem ostanku u

39 AIM, pismo dr. Ljubomira Marakovića, Ivanu Merzu s nadnevkom 24. XI. 1914.

40 AIM, pismo Ivana Merza, ocu Mavri Merzu s nadnevkom od 14. X. 1914. 
akademiji, pa ocu odmah odgovara pismom koje datira sa 3. studenim. U pismu on apostrofira ocu:

Ja neću i ne mogu ni pod kojim uvjetom dalje da ostanem u Vojnoj akademiji. Jedini razlog, koji se još navodi u prilog mom ostanku ovdje, jest moj tjelesni razvitak. No ni to ne stoji [...] Redovito sjedimo u klupi 7 do 8 sati dnevno. Više nego u srednjoj školi [...]. Treba računati da je od 22 do 6 , dakle 8 sati sna premalo za mene. (To mama zna vrlo dobro). Pomanjkanje sna, kako sam primijetio, također je isto tako štetno za moje oči, koliko i čitanje pri svjetlosti lampe. Vjerujem da sam naveo dovoljno razloga i da ćeš mi sada izići u susret kao prema dobrom djetetu i da ćeš mi dozvoliti da upišem fakultet. ${ }^{41}$

Stoga je molio oca da ga oslobodi obveza u Vojnoj akademiji, razlažući potanko koliko bi stajao život u Beču (kazalište, slike, kava) ističući da jedan student u Beču može živjeti dobro, a da ne potroši mnogo. Zatim tu je i pitanje društva: dovoljno je reći da su u Beču osobe koje su u kontaktu s prof. Marakovićem, a da je on sam bio u Beču tijekom studija. »Dok sam bio s njima bio sam zaista sretan što sam napokon mogao biti sa ljudima poštenim i inteligentnim $\ll .{ }^{42}$ Ujedno ga je zamolio da umiri mamu, koja je bila tužna zbog svih događaja koje je njezin sin proživljavao u Wiener Neustadtu. Svoje pismo je završio riječima: »To bi bilo sve. Vjerujem da se Ti i mama slažete. Ako ne, ne znam da li ću u životu ikada biti sretan. «43 Bila je to jasna poruka kojom je želio naznačiti da uskoro planira donijeti važnu odluku, ali i apel roditeljima da više ne može izdržati u takvom ambijentu, te da budu spremni na neki novi scenarij.

\section{Odluka je donesena}

Kako u realnoj gimnaziji, koja je bila tehničkog usmjerenja, nije učio latinski jezik započeo je s učenjem intenzivno kako bi mogao i položiti taj ispit koji mu je uz maturu bio presudan za upis na studij književnosti na Bečkom sveučilištu. Svoju zadaću je shvatio vrlo ozbiljno jer je dnevno radio i po četiri sata kako bi mogao izići na ispit. Na Vojnoj akademiji svakodnevno je doživljavao provokacije i podsmijeh svojih kolega upravo zato što je učio latinski. O tome u svojem dnevniku piše:

Moj je opstanak ovdje nemoguć. Hoću da budem slobodan, hoću da zađem u dubinu stvari, a ne da učim ono što predavači samo površno znaju. Učeći tehničke znanosti moram se diviti veličini Stvoritelja koji je izveo tako divne, minuciozne zakone, a ne samo učiti ono što ćemo upotrijebiti da ubijamo mile nam i nepokvarene narode na milijune koji će svijet preporoditi. Ovome su ratu krivi tirani koji ugnjetavaju narode, koji vjeru ugnjetavaju i čovjek bi postao nihilist da ne zna da je toliko milijuna inteligencije isti takav tiranin, egoist kojemu je »ja « sve, a drugi ništa. Poradi toga je mirni rad, odgoj samog sebe, geslo čovjeka. ${ }^{44}$

41 AIM, pismo Ivana Merza, ocu Mavri Merzu s nadnevkom od 3. XI. 1914.

42 Isto.

43 Isto

44 DIM, 8. XII. 1914., 97. 
U sklopu praktičnih vježbi, 9. prosinca 1914. bio je na gađanju puškom bojevim streljivom. Nije bio oduševljen svojim vojničkim vještinama. Proučavao je taj dan Livija. O tome Merz piše: »Upravo sam došao do Coriolana. On je uistinu bio junak, ali slabiji nego u Shakespearea. Mislim da je Shakespeare iz Livija crpio građu [...]. «45 Akademija nije ispunila njegova očekivanja. Smatrao je da se mnogo uči ali stvari koje nisu praktične i za život. Jedini čovjek na akademiji s kojim je mogao razgovarati bio je Klein, koji je bio dobar poznavatelj egipatske povijesti. Merz njemu posvećuje nekoliko redaka u dnevniku:

Uvjerio sam se da mnogo znade. No, u njemu ima mnogo talijanskog. [...] Inače nema u njemu one moralne visine - loš mu je duševni odgoj. Čitajući neke knjige, drži Isusa za čovjeka neke stanovite sekte, a opet se čudi starim proročanstvima. No, o tome ne razmišlja. Nije uočio onaj sjajni tijek historije - onu veličanstvenu borbu oko Istine. Hvali historijske fakte, državna uređenja (Cato je bio za njega najveći Rimljanin) i to ga zanima. Nitko ga nije upozorio na ono visoko, jedino postojeće. Želi doći na univerzu. Možda će mu se jednom oči otvoriti. ${ }^{46}$

Merz se u Akademiji rado prisjećao svoje prve ljubavi Grete Teschner i obljetnice njezine smrti. Greta Teschner rođena je 18. prosinca 1896. i Merz se s njome rado družio u Banjoj Luci. Iako je bila protestantske vjere, cijenio ju je zbog njezine srdačnosti i dobronamjernosti. Nakon što ju je iskoristio jedan stariji muškarac počinila je samoubojstvo.

Srce je moje uzburkano čuvstvima. Uspomena na Gretu, ganjanje po parku, prvi ples, prvi sastanak. Naše šale i sve slično. Šetnja po brdima i čitanje Schillera. Večera u njihovoj kući, scena kod pijanina, prvi poljubac, zlatno-smeđe kose [...]. Ono što bijaše gadno - prošlo je. Jedina je uspomena koja živi, ona šesnaestogodišnja i ja toliko. Da, 18. XII. bit će joj osamnaest godina. I ja sam pridonio dio njenoj smrti. Bio sam životinja. To će biti i dublji uzrok što se je otrovala. Poradi zlog odgoja te poradi toga što u njoj viđahu samo životinju, dočim je u nje bilo mnogo i mnogo lijepih svojstava i mnogo inteligencije. Iznenađivala me je svojim poznavanjem historije i književnosti. Kadno je jednom došla u Banju Luku, sastali smo se pred Božićevom kućom. Bio je i Pajić. Upravo mi reče da je pročitala Frühlingsfluten. Čini mi se, to je bio naš zadnji razgovor. Smrt — grozna smrt — ju je odnijela. Svevišnji, veliki Bože, molim Te, daj da grešnica koja je dosta trpjela na ovome svijetu, koja je žrtva pokvarenosti društva, vidi bar djeličak Tvoje ljepote! Gubitak nade nek nije za nju. ${ }^{47}$

\section{Odlazak s Vojne akademije}

Merz je bio sve sigurniji u svoju odluku da zauvijek napusti Bečko Novo Mjesto i ode na studij književnosti u Beč. Osudio je nemoralnu okolinu u kojoj je bio prisiljen živjeti i planirao svoj odlazak iz Akademije. U svojim razmišljanjima on u svojem Dnevniku spominje neke momente koji su za njega iracionalni i izazivali čuđenje. 
Sjećam se na prve dane ovdje. Bilo mi je jako teško. Sjedeći s onima iz drugog tečaja kod jednog stola bio sam prinuđen slušati stvari na koje nikad nisam ni pomislio. Razbacivajući se kruhom pričali su čitavo vrijeme o cijeni ove i one ženske, o strašnim svinjarijama. S nekom strašnom ljutinom otišao sam od stola te plakao što sam prisiljen živjeti u takvom društvu. Pod takvim dojmom pisao sam kući i prijateljima očajna pisma. Da, privikao sam se na sve to. Više me ne bode toliko kad čujem gdje se psuje Bog, kad se govore svinjarije; iako me strašno uzruja, to ipak o svemu razborito sudim i mislim si što je uzrok ovom zlu: odgoj. ${ }^{48}$

Kao čovjek bio je svjestan svojih tjelesnih slabosti, napose onih koje se odnose na sposobnost izvođenja vojničkih vježbi. O tome kaže: »Najjednostavnije tjelesne vježbe ne mogu. A uz to su mi oči slabe. Svi me pitaju što spavam. Uistinu, ne mogu gledati jedan predmet: ne mogu naime oba oka u nj usmjeriti. Da imam dobre naočale, moguće bih sve bolje razumijevao [...].«49

Ozbiljna vojnička zadirkivanja i njegove reakcije, koje sam kritizira, doživio je 14. prosinca, kada su ga kolege Černyi i Sondraček išamarali desetak puta bez ikakva povoda, zbog čega je bio toliko iziritiran da je više iz šale izvadio nož koji je nehotice bacio za kolegom Palihom, ali sve u cilju da nasilnike zastraši. Bio je sam kako piše šokiran i prestrašen njihovim i svojim postupcima.

Svoj odlazak s Vojne akademije zaključuje u svojem dnevniku riječima:

Zaključujem dnevnik u akademiji [...] Roditelji čine zločin, ako djecu od sebe daju u takve škole, gdje učitelj samo predaje i kad iz razreda izađe, zaboravi, da je učitelj. To je upravo strašno [...]. Dnevnik završujem i molim Svevišnjega, koji je odredio put suncu i zvijezdama, smjer svakoj stabljici i zadaću svakom mravu, da i meni pokaže put čistoći, velikoj umjetnosti, svemu najvišemu i vječnomu. Neka se opet i opet Faust probudi koji je ovdje kano zaspao! ${ }^{50}$

Odobrenjem za dopust Carske i kraljevske terezijanske vojne akademije koju je potpisao zapovjednik Vojne akademije, Feldmarschall — Leutnant Karl von Strasser Edler, »dozvoljen je odlazak vojnom akademcu Ivanu Merzu, 1. godine studija, razreda 1a na Božićne blagdane u Zagreb u Hrvatsku u vremenu od 5 dana. Taj dopust nastupa 23. prosinca 1914. a završava 28. prosinca 1914. u 9.00 sati. Wiener Neustadt, 22. dezember 1914. godine. «1

Ivan Merz napustio je Vojnu akademiju u Bečkom Novom Mjestu 23. prosinca 1914. rano ujutro s čvrstom odlukom da se više tamo neće vratiti. Bilo je to veliko olakšanje za njega. Božićne blagdane proveo je u krugu obitelji u Banjoj Luci, gdje je uspio uvjeriti roditelje da ga upišu na Sveučilište u Beču. Pristao je da to bude i studij prava po izboru njegove majke, iako je znao da su njegova ljubav filozofija i književnost. Uzeo je vojnu uniformu i poslao je na Vojnu akademiju u Bečko Novo Mjesto s dopisom da se Hans Merz neće više tamo vratiti.

51 AIM, Urlaubsbewilligung, dem Militärakademiker Johann Merz, Wr. Neustadt, am 22. Dezember 1914. 


\section{Zaključak}

Nakon mature, na nagovor roditelja Ivan Merz upisao je Vojnu akademiju u Bečkom Novom Mjestu. Imao je 17 godina i 9 mjeseci i bilo je to za njega jedno posve novo iskustvo. Život u akademiji bilo je okružje u kojem nije prepoznao sebe ni svoj cilj za kojim je težio. Boravak na Vojnoj akademiji bio mu je vrlo mučan ispunjen gorčinom i nezadovoljstvom. Zbog niske razine kulturnog ophođenja, psovki, podmetanja, nemorala, nemogućnosti da sudjeluje u Euharistiji vojnički život nije mu ulijevao sigurnost u dobar izbor životnog poziva.

Iako je Vojna akademija u Bečkom Novom Mjestu bila ugledna i imala je dugu tradiciju, Merz nije bio oduševljen životom i radom u takvoj sredini. Nije mu ulijevala povjerenje ni činjenica da su akademiju pohađala djeca uglednih plemića i časnika, štoviše bio je posvema siguran da je na pogrješnom mjestu. Osim niske razine kulture ophođenja, mučio ga je i problem nemogućnosti da slobodno ispovjeda svoju vjeru i prakticira je na način kako je to do tada naučio. Bio je konsterniran modelom ponašanja većine pitomaca i časnika zaposlenih na Vojnoj akademiji. Ni uvjeravanja njegova oca Moritza nisu ga ohrabrila a ni uvjerila da treba ostati i dalje u akademiji. Svoj pohod Beču 6. prosinca 1914. iskoristio je za susret s Hrvatskim akademskim društvom »Hrvatska«, koje su činili mladi studenti iz Hrvatske i Bosne. Bio je svjestan da pripada tomu krugu mladih studenata s željom da nastavi studij književnosti upravo na Bečkom sveučilištu i da se školuje za ono zanimanje koje će s ljubalju i radošću obavljati.

Nakon niza razgovora i opsežne korespondencije s ocem Moritzom, mladi je Merz donio konačnu odluku da napusti vojni poziv i Vojnu akademiju u Bečkom Novom Mjestu. Učinio je to uoči Božića 22. prosinca 1914. godine, nakon tromjesečnog boravka u Bečkom Novom Mjestu. 
Ivan Merz, Student at the Military Academy in Wiener Neustadt, 1914

Zdravko Matić*, Krešimir Lagetar**

Summary

The authors' research on Ivan Merz's sojourn at the Wiener Neustadt Military Academy is based on archival material, new articles, as well as recent literature. Though not by his own choice, Merz entered the Military Academy in Wiener Neustadt after graduation, as his parents wished. It was a difficult period in his life, as he himself admits in his Diary and later to his secondary school Professor Ljubomir Marakovic,, Ph.D. Rudeness and immorality at the Military Academy were a daily occurrence and were contrary to his nature, as was also the life-long job which awaited him. His desire and penchant for studying literature and becoming a teacher prevailed, and so with his parents' consent he left the Military Academy, having spent three months there, namely, from September 12 to December 22, 1914. Ivan Merz was beatified by Pope John Paul II on June 22, 2003 in Banja Luka, Bosnia.

Key words: Ivan Merz, scholar, Theresianische Militär Academy (Theresian Military Academy), Wiener Neustadt, Professor Ljubomir Maraković, father, study

* Associate Professor Zdravko Matić, Ph.D., Croatian Military Academy »Petar Zrinski«, Zagreb, Croatia. Address: Ilica 256b, 10000 Zagreb, Croatia. E-mail: zdmatic@gmail.com

** Krešimir Lagetar, B. Ed., Laslovo Elementary School. Address: Školska 1, 31214 Laslovo, Croatia.E-mail:klagetar@gmail.com 